\title{
Analysis of the genetic variability of peach palm (Bactris gasipaes) in the Yurimáguas region, Peru, using molecular RAPD markers
}

\section{Análise da variabilidade genética de Pupunha (Bactris gasipaes Kunth) da região de Yurimáguas, Peru, por meio de Marcadores Moleculares RAPD}

\section{Cirlande Cabral da SILVA*; Doriane Picanço RODRIGUES²; Charles Roland CLEMENT³; Spartaco ASTOLFI FILHO ${ }^{4}$}

\begin{abstract}
${ }^{1}$ Mestre em Genética e Evolução e Doutor em Ensino de Ciências; Instituto Federal de Educação, Ciência e Tecnologia do Amazonas (IFAM), Departamento Acadêmico de Educação Básica e Formação de Professores (DAEF); Av. sete de setembro, 1975, Centro, 69029-120, Manaus, Am. Email: cirlandecabral@gmail.com (autor para correspondência)

${ }^{2}$ Doutora em Biotecnologia; Universidade Federal do Amazonas (UFAM), Instituto de Ciências Biológicas, Laboratório de Evolução Aplicada, Av. Gal. Rodrigo Otávio Jordão Ramos, 3000, Coroado, 69.077-000, Manaus, AM. Email: doriane@ufam.edu.br

${ }^{3}$ Doutor em Horticultura; Instituto Nacional de Pesquisas da Amazônia (INPA), Av. André Araújo, 2936, Petrópolis, 69.060-001, Manaus, AM. E-mail: cclement@inpa.gov.br

${ }^{4}$ Pós Doutorado em Engenharia Genética; Universidade Federal do Amazonas (UFAM), Instituto de Ciências Biológicas, Centro de Apoio Multidisciplinar (CAM), Av. Gal. Rodrigo Otávio Jordão Ramos, 3000, Coroado, 69.077-000, Manaus, AM. Email: spartaco@ufam.edu.br
\end{abstract}

Recebido em: 02-08-2017; Aceito em: 04-11-2017

\begin{abstract}
Molecular markers were used to verify the existence of one or more primitive peach palm landraces, including Pampa Hermosa, in the microregion near Yurimáguas, Peru. This region provides the highest amount of seeds for peach palm heart agribusinesses in Brazil. In this analysis, we used 120 peach palm plants (Bactris gasipaes var. gasipaes) from four river basins around Yurimáguas. We used six primers, generating 73 RAPD markers. The heterozygosity ranged from 0.29 to 0.31 , with a mean of 0.32 , and the percentage of polymorphism ranged from 80.8 to 86.6, with a mean of 90.4. The dendrogram, based on Jaccard Similarity, presented eight groups, but it did not present groups formed by the water basins. The average gene flow was high, ranging from 11.41 to 18.89 , as expected for populations within a same landrace. The analysis of the genetic diversity in this set of plants showed a common genetic basis among the plants. Nei's Genetic Distances were low, varying between 0.012 and 0.027 . This suggests that such populations are very similar to each other, and that there is only one landrace in the region. Therefore, we propose the existence of only one landrace in the Yurimáguas region and the name "Pampa Hermosa" should be adopted.
\end{abstract}

Additional keywords: gene flow; genetic analysis; genetic distances; primitive landraces.

\section{Resumo}

Marcadores moleculares foram utilizados para verificar a existência de uma ou mais raças primitivas de pupunha, além de Pampa Hermosa, na microrregião próxima de Yurimáguas, Peru, que fornece a maioria das sementes para o agronegócio de palmito de pupunha no Brasil. Nesta análise, foram utilizadas 120 plantas de pupunha (Bactris gasipaes var. gasipaes) de quatro bacias hidrográficas ao redor de Yurimáguas. Seis iniciadores foram utilizados, gerando 73 marcadores RAPD. A heterozigosidade variou de 0,29 a 0,31, com média de 0,32, e a porcentagem de polimorfismo variou de 80,8 a 86,6, com média de 90,4. O dendrograma baseado nas Similaridades de Jaccard apresentou oito grupos, porém sem apresentar grupos definidos com base nas bacias hidrográficas. O fluxo gênico médio foi alto, variando de 11,41 a 18,89, como esperado para populações dentro de uma raça. $A$ análise da diversidade genética nesse conjunto de plantas mostrou uma base genética comum entre essas plantas. As Distâncias Genéticas de Nei foram muito pequenas, variando de 0,012 a 0,027, sugerindo que essas populações são muito similares entre si e que existe uma só raça na região. Portanto, foi proposta a existência de apenas uma raça na região de Yurimáguas, e o nome Pampa Hermosa deve ser conservado.

Palavras-chave adicionais: análise genética; distâncias genéticas; fluxo gênico; raças primitivas.

\section{Introduction}

Brazil is the world largest producer and consumer of palm heart with an annual production of 103,419 t, mostly from açaí (Euterpe oleracea) and juçara [(Euterpe edulis) (Galdino \& Clement, 2008)]. Among the advantages of peach palm, in comparison to other species, are precocity of cutting, good productivity, good tillering, rusticity, and no enzymatic darkening (Kalil Filho et al., 2010). In 2004, there were 
more than 28.000 ha of cultivated area in the state of São Paulo alone, and this area continues to expand rapidly. The Brazilian market still shows no signs of saturation, although it has been shaken by two cases of botulism in the late 1990. Expansion is limited by seed import problems. Such problems could be avoided if Brazilian improvement projects received an adequate financial support to service seed producers.

The peach palm plantations in Brazil are represented by the populations of Yurimáguas (Peru), Pampa Hermosa, and Benjamin Constant (AM, Brazil), from the Putumayo breed (macrocarpa) improved by two generations (Kalil Filho et al. 2010). The latter is found along the Solimões and Amazonas rivers in Brazil and adjacent areas in Colombia and Peru, and presents large fruits with high starch (Sousa et al., 2001). Although this breed was originally domesticated for the production of fruits for human consumption, its seeds, originated from progenies selected for palmito production, have been used in the formation of commercial peach palm plantations in different regions of Brazil (Clement, 1988). The selection of such progenies has taken into account characters, proposed by Clement (1997), as components of an ideotype suitable for palmito production, among which petiole / rachis without spines, high relative growth rate, continuous tiller production, harvest of palm heart less than 12 months old and good size palm heart.

The market for peach palm heart grows in function of seeds of the primitive Pampa Hermosa landrace and landrace populations neighboring the Yurimáguas region (Bovi, 1997). Some Brazilian producers use this germplasm.

Yurimáguas is located on the western margin of the Huallaga River at the Department of Loreto in the Peruvian Amazon. It is a source for most peach palm seeds that supply the peach palm agribusiness in Brazil. The district of Yurimáguas occupies the banks of the Huallaga river, forming the axis of the district. Paranapura, Shanusi \& Cuiparillo river basins flow into the Huallaga river near the city of Yurimáguas. They contain the main populations of the region's peach palm species.

The Yurimáguas district underwent three prospects on peach palm genetic resources by the INPA (Clement et al. 2002): the first was made in 1980 by Wanders B. Chávez Flores; the second was made in 1983 by an international expedition financed by the US-AID; the third was made in 1991 by W.B. Chávez Flores with support from the CNPq. After the collection of 1983, Mora Urpí \& Clement (1988) identified a primitive landrace in the Pampa Hermosa region on the Shanusi River, and a hybrid population around the city of Yurimáguas on the Huallaga River. The authors also raised the hypothesis of the existence of other landraces in the Yurimáguas region based on the extensive genetic variability observed in the markets and backyards of that city.

The genetic variability of the Yurimáguas region has been subject of several studies using mole- cular markers. Clement et al. (1997) used isoenzymes to compare the Pampa Hermosa landrace with the Putumayo and Guatuso landraces, and found more genetic variability in the Yurimaguas region than in other regions. Rodrigues et al. (2004) used RAPD markers to validate the primitive Pampa Hermosa landrace and observed a heterozygosity of 0.26 and a polymorphism percentage of 75.2 , slightly lower than the Putumayo landrace $(0.27 ; 77 \%)$, which is adjacent to the Yurimaguas region. Adin et al. (2004) used AFLP markers to analyze landrace variability on the Cuiparillo and Paranapura rivers, and found a heterozygosity of 0.24 and 0.25 and a polymorphism of $61.6 \%$ and $65.5 \%$, respectively. They observed very little genetic divergence between rivers (Gst $=0.025$ ) and a high gene flow $(\mathrm{Nm}=4.8)$.

The objective of this study is to use molecular RAPD markers to verify the existence of one or more landraces besides Pampa Hermosa in the microregion near Yurimáguas, including the rivers Cuiparillo, Paranapura, Shanusi (home of the Pampa Hermosa landrace) and Huallaga.

\section{Material and methods}

A total of 120 plants from four Bactris gasipaes populations were analyzed. 30 individuals of each population are stored in the Active Germplasm Bank of INPA, BR 174, Km 38, Manaus, Amazonas state, Brazil. The analyzed populations were Shanusi river (30 plants from 15 accessions), Paranapura river (30 plants from 14 accessions), Upper Huallaga river (30 plants from 10 accessions) and Cuiparillo river (30 plants from 6 accessions). These sampled accessions were selected because they presented a good geographic coverage in the four river basins.

The DNA was extracted using the DNAsy Plant Mini-Kit by Quiagen using $100 \mathrm{mg}$ of the apical meristem of a lateral stipe, as proposed by Clement et al. (1997) for enzyme extraction. It was quantified it on $0.8 \%$ agarose gel stained with ethidium bromide and obtained, on average, approximately $14 \mathrm{ng}$ of DNA/ $\mathrm{Ll}$. RAPDs were obtained according to Williams et al. (1990) considering the modifications made by Rodrigues (2001). Each amplification reaction, in a final volume of $30 \mu \mathrm{l}$, contained $3 \mu \mathrm{l}$ of genomic DNA $(5 \mathrm{ng} / \mu \mathrm{l}), 3 \mu \mathrm{l}$ of $\mathrm{dNTP}(2.5 \mathrm{mM}), 3.6 \mu \mathrm{l}$ of $\mathrm{MgCl}_{2}$ $(25 \mathrm{nM}), 5 \mu \mathrm{l}$ of primer $(10 \mathrm{ng} / \mu \mathrm{l}), 0.5 \mu \mathrm{l}$ of Taq Polymerase enzyme (CENBIO/RS) and $3 \mu \mathrm{l}$ of $10 \mathrm{X}$ buffer (Tris- $\mathrm{HCl} 200 \mathrm{mM}, \mathrm{pH}=8.6, \mathrm{KCl} 500 \mathrm{mM}$ ) (Tris$\mathrm{HCl} 200 \mathrm{mM}, \mathrm{pH}=8.6, \mathrm{KCL} 500 \mathrm{mM})$. The samples were amplified using a thermal cycler (Perkin Elmer 9600) programmed for 1 step of 1 min at $94^{\circ} \mathrm{C}$, 40 cycles of $1 \mathrm{~min}$ at $92^{\circ} \mathrm{C}, 1 \mathrm{~min}$ at $36^{\circ} \mathrm{C}$ and $2 \mathrm{~min}$ at $72{ }^{\circ} \mathrm{C}$, plus 1 step of $3 \mathrm{~min}$ at $72^{\circ} \mathrm{C}$. The primers were the same as those used by Rodrigues et al. (2004): OPA-20, OPA-9, FC-13, OPA-5, OPA-8 and OPA-18 (Operon Technologies).

The amplified products were separated on agarose gel (1.5\%) in a TBE buffer at $120 \mathrm{~V}$ for 4 hours. Then, they were stained with $0.5 \mathrm{mg} / \mathrm{mL}$ ethidium bromide, visualized and photographed for further 
interpretation. One Juruá landrace plant kept in gels was used as a control (with one replica on the left side and one in the middle of the gel).

Monomorphic and polymorphic bands were coded as present or absent based on resolution and degree of amplification, as described by Ferreira \& Grattapaglia (1998), to create a binary matrix. The Jaccard Similarity was estimated based on that binary matrix. We designed a dendrogram using the UPGMA (unweighted arithmetic mean) algorithm and the program NTSYS-pc (Rohlf, 1990). We then estimated heterozygosity, assuming the absence of the marker as recessive (Weir, 1996), and percentage of polymorphism for each population using the TFPGA program (Miller, 1997). We evaluated the relations among populations by Nei's Genetic Distance (1978) and the differences in allele frequencies among populations by the Exact Test (Raymond \& Rousset, 1995), also using the TFPGA program. We calculated the gene flow $[\mathrm{Nm}=0.5(1-\mathrm{sT}) / \mathrm{sT})]$ among populations taking into account st estimates (Slatkin \& Barton, 1989) using the POPGEN program, version 1.31 (Yeh et al., 1999).

\section{Results and discussions}

According to PCR amplification, the six primers generated 73 good markers because they presented a good resolution. It was obtained a mean of 12.1 markers per primer, a value lower than that obtained by Sousa et al. (2001) and Rodrigues et al. (2004), 80 and 113, respectively. This difference in the number of markers may have occurred because the authors used two additional primers, generating a greater number of RAPD fragments. The number of polymorphic markers in this analysis was 64 (87.6\%), a number similar to that found by Sousa et al. (2001) (88.7\%) and Rodrigues [(2001) (89\%)]. The estimated heterozygosity for this set of plants was 0.32 , i.e., it presents a high similarity among populations (Table 1). The percentage of polymorphism of the set was 90.4 (the criterion was 99\%). It was significantly higher than any individual population (Table 1), suggesting the existence of private alleles in the rivers. Rodrigues et al. (2004) obtained a slightly lower percentage of polymorphism (89.4\%) possibly in function of the number of individuals sampled. The high polymorphism observed among the plants of these populations reflects the high variability this species presents, which also manifests itself in its morphological characteristics (Mora Urpí, 1991). Such high variability is the reason for the hypothesis of existence of other landraces in the Yurimáguas region (Mora Urpí \& Clement, 1988).

Table 1 - Heterozygosities and percentage of polymorphic loci (95\% and 99\%) in the four populations of peach palm (Bactris gasipaes) on the Yurimáguas region, Peru.

\begin{tabular}{lcccc}
\hline \multirow{2}{*}{ Population } & \multirow{2}{*}{ Number of plants } & \multirow{2}{*}{ Heterozygosity } & \multicolumn{2}{c}{$\%$ of Polymorphism } \\
\cline { 4 - 5 } & 30 & 0.31 & 80.8 & $99 \%$ \\
\hline Paranapura & 30 & 0.29 & 79.4 & 80.8 \\
Pampa Hermosa & 30 & 0.31 & 80.8 & 84.9 \\
Huallaga Alto & 30 & 0.30 & 82.1 & 86.3 \\
Cuiparillo & 120 & 0.32 & 82.2 & 90.4 \\
\hline Total & &
\end{tabular}

The dendrogram, based on Jaccard Similarity, comprised eight groups. There were no groups defined according to river basin (Table 2). Group 1, for example, contained 16 of the 30 individuals of Cuiparillo, the group 5 contained 8 , and the group 8 contained 4 . This evidences that this population has many similarities with the other three populations. The absence of a structure differentiating the populations suggests that they are very similar.

Table 2 - Number (and percentage) of peach palm individuals (Bactris gasipaes) on the Yurimáguas region distributed into groups in the dendrogram based on Jaccard Similarity.

\begin{tabular}{crcccc}
\hline \multirow{2}{*}{ Groups } & \multirow{2}{*}{ No. } & \multicolumn{5}{c}{ Population } \\
\cline { 3 - 6 } & & Paranapura & P. Hermosa & Upper Huallaga & Cuiparillo \\
\hline 1 & 18 & $1(5.5 \%)$ & - & $1(5.5 \%)$ & $16(88 \%)$ \\
2 & 6 & - & $5(84 \%)$ & $1(16 \%)$ & - \\
3 & 10 & $2(20 \%)$ & - & $7(70 \%)$ & $1(10 \%)$ \\
4 & 11 & $9(81.8 \%)$ & $2(18.2 \%)$ & - & - \\
5 & 37 & $9(24.3 \%)$ & $15(40.5 \%)$ & $5(13.5 \%)$ & $8(21.7 \%)$ \\
6 & 9 & $5(55.6 \%)$ & $4(44.4 \%)$ & - & - \\
7 & 18 & $4(22.2 \%)$ & $4(22.2 \%)$ & $9(50 \%)$ & $1(5.6 \%)$ \\
8 & 11 & - & - & $7(63 \%)$ & $4(36.3 \%)$ \\
\hline Total & 120 & 30 & 30 & 30 & 30 \\
\hline
\end{tabular}


The Exact Test (Raymond \& Rosset, 1995), used to compare allele frequencies among the four populations, showed that the Cuiparillo population is different from the others (vs. Huallaga, $p=0.047$; vs. Paranapura, $p=0.0001$; vs. Pampa Hermosa, $p=0.014$ ). The other populations are not different from each other. The difference between Cuiparillo and the other populations was not evidenced by the Jaccard dendrogram, since half of the individuals were present in group 1 and other individuals were apparently rando- mized in the dendrogram (Table 2). It is believed that such a difference occurred because the number of Cuiparillo accessions sampled was lower than the number sampled in the other river basins, increasing the number of related samples.

Nei's genetic distances (1978) were low (the highest was 0.027). This proves that these populations are very similar and cannot be considered as different landraces (Figure 1). This was also observed by Adin et al. (2004).
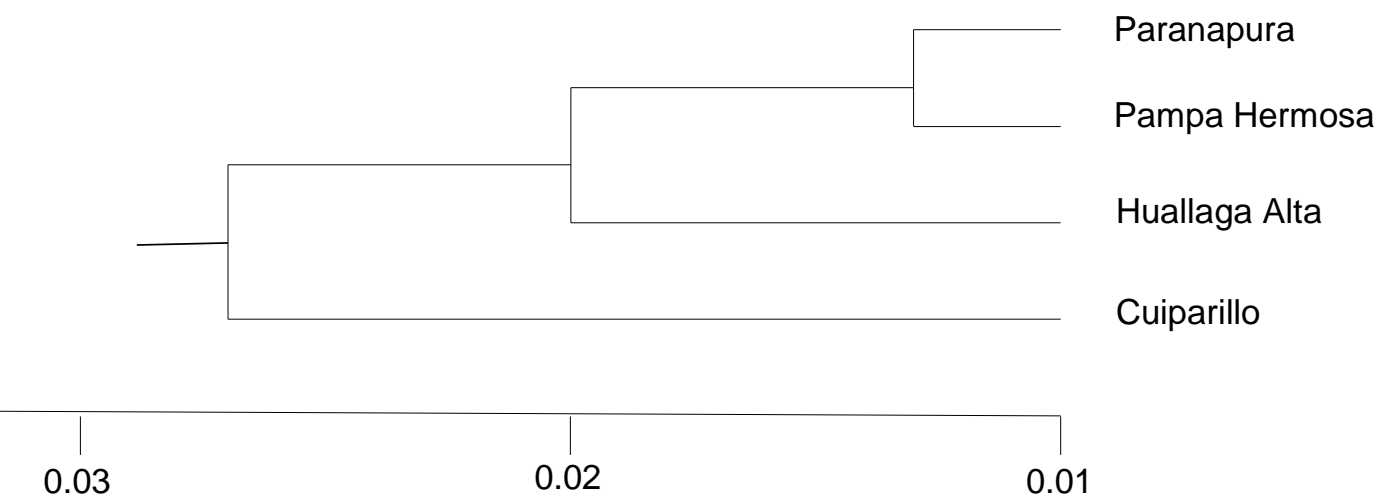

Nei's Genetic Distance (1978)

Figure 1 - Dendrogram based on Nei (1978) of four peach palm populations (Bactris gasipaes) evaluated using molecular RAPD markers on the Yurimáguas region, Peru.

The average gene flow was high for this group of populations (Table 3 ) and similar to that observed by Rodrigues et al. (2004) upon analyzing Central America landraces (Utilis/Tuíra $=15.7$, Tuíra/Guatuso $=10.3$, and Guatuso/Utilis = 12.4). This suggests the existence of a single landrace. These values are significantly higher than those found by Adin et al. (2004) because the author used a less precise marker for this type of analysis.

Table 3 - Gene flow among the four populations of peach palm on the Yurimáguas region, Peru, and fraction of diversity among these populations (Gst) in the upper diagonal.

\begin{tabular}{lcccc}
\hline Gene Flow & Cuiparillo & Upper Huallaga & Paranapura & P. Hermosa \\
\hline Cuiparillo & ----- & 0.02 & 0.04 & 0.03 \\
Huallaga Alto & 18.57 & -----03 & 0.02 & 0.02 \\
Paranapura & 11.41 & 16.60 & ----- & ----- \\
Pampa Hermosa & 11.87 & 14.72 & 18.89 & \\
\hline
\end{tabular}

The mean of the estimated total diversity analyzed in this set of peach palm populations $\left(\mathrm{H}_{\mathrm{T}}\right)$ was 0.32 , a value similar to that found by Rodrigues et al. (2004) (0.30). The diversity among the populations (Hs) was 0.31. The diversity fraction among the populations (Gst) was 0.04 , slightly higher than that estimated by Adin et al. [(2004) (0.025)] upon analyzing the Gst among peach palm populations along the Paranapura and Cuiparillo rivers.

\section{Conclusion}

The lack of a population structure in the groups formed according to Jaccard Similarity shows that the populations are not very distinct. The Nei's Genetic Distances (1978) evidenced a reduced genetic base. All populations were highly related. The high gene flow among the analyzed populations also showed that they are not different from each other, although Cuiparillo was different regarding its allelic frequency. The genetic diversity analyzed in this set of plants showed a common genetic basis among plants. Therefore, we propose the existence of only one landrace in the Yurimáguas region and the name "Pampa Hermosa" should be adopted.

\section{Acknowledgements}

The authors are grateful to the Banco da Amazônia SA for financing the project "Molecular markers (RAPDs) for the discrimination of primitive peach palm landraces (Bactris gasipaes) kept in Active Germplasm Bank", coordinated by Clement and Astolfi Filho, and to the Foundation Djalma Batista for the administrative and logistical support. 


\section{References}

Adin A, Weber JC, Sotelo Montes C, Vidaurre H, Vosman B, Smulders MJM (2004) Genetic differentiation and trade among populations of peach palm (Bactris gasipaes Kunth) in the Peruvian Amazon implications for genetic resource management. Theoretical and Applied Genetics 10(8):1564-1573.

Bovi ML (1997) A Expansão do cultivo da pupunheira para palmito no Brasil. Horticultura Brasileira 15(2): 183-185.

Clement CR, Aradhya MK, Manshardt MR (1997) Allozyme variation in spineless pejibaye (Bactris gasipaes Palmae) \{Variação isoenzimática em pupunha inerme\} 51(2):149-157.

Clement CR (1988) Domestication of the pejibaye palm (Bactris gasipaes): past and present. Advances Economic Botany 3(6):155-174.

Clement CR, Sousa NR, Rodrigues DP, Astolfi Filho S, Moreno YN, Pascual VT, Gallego Rodríguez FJ (2002) Use of AFLPs to distinguish landraces of pejibaye (Bactris gasipaes) in Brazilian Amazonia. Scientia Agricola 59 (4): 749-753.

Ferreira ME, Grattapaglia D (1998) Introdução ao uso de marcadores moleculares em análise genética. Embrapa-CENARGEN, Brasília. 220p.

Galdino NO, Clement CR (2008) Palmito de pupunha (Bactris gasipaes Kunth), composição mineral e cinética de enzimas oxidativas. Ciência e Tecnologia de Alimentos 6(28):540-544.

Kalil Filho NA, Clement CR, Resende MDV, Farias Neto JT, Bergo CL, Yokomizo GKI, Kaminski PE, Yuyama K, Modolo VA (2010) Programa de melhoramento genético de pupunha na Embrapa, IAC e Inpa. Colombo: Embrapa Florestas, 34p. (Embrapa Florestas. Documentos, 205.

Miller MP (1997) Tools for Population Genetic Analysis (TFPGA), version 1.3. Northen Arizona University, Tucson.

Mora-Urpí J (1991) Diversidad genética en pejibaye. II. Origen y domesticación. In: Mora Urpí J, Szott LT, Murillo M, Patinõ VM (Eds). IV Congreso Internacional sobre Biología, Agronomía e Industrialización del Pejuayo. Editorial Universidad de Costa Rica, San José, Costa Rica, 21-29.
Mora Urpi J, Clement CR (1988) Races and population of peach palm found in the Amazon basin. Final report on Peah Palm Germplasm Bank. INPA, Manaus, p.7894.

Nei M (1987).Genetic distance between populations. American Naturalist, Washington, 6(106):.283-292.

Raymond ML, Rousset R (1995) An exact test for population differentiation. Evolution 7(49):1280-1283.

Rodrigues DP (2001) Análise das morfo-raças primitivas de pupunha (Bactris gasipaes Kunth) mantidas no banco ativo de germoplasma de pupunha com marcadores moleculares RAPD. UnB (Dissertação em Biologia Molecular).

Rodrigues DP, Astolfi Filho S, Clement CR (2004) Molecular marker-mediated validation of morphologically defined landraces of pejibaye (Bactris gasipaes) and their phylogenetic relationships. Genetic Resources and Crop Evolution 51(8):871-882.

Rohlf FJ (1990) NTSYS-pc. Numerical taxonomy and multivariat analysis system, version. 1.6. Exeter Software, Setauket, NY.

Slatkin M, Barton NH (1989) A comparison of three indirect methods for estimating average levels of gene flow. Evolution 7(43):1349-1368.

Sousa NR, Rodrigues DP, Clement CR, Nagao EO, Astolfi-Filho S (2001) Discriminação de raças primitivas de pupunha (Bactris gasipaes) na Amazônia brasileira por meio de marcadores moleculares (RAPD). Acta Amazonica 31(4):539-545.

Weir BS (1996) Genetic Data Analysis II: Methods for Discrete Population Genetic Data. Sinauer Associates, Inc. Sunderland, Massachusetts. 445 p.

Williams JGK, Kubelik AR, Livak KJ, Rafalski JA, Tingey SV (1990) DNA polymorphisms amplified by arbitrary primers are useful genetic markers. Nucleic Acid Research 3(18):6531-6535.

Yeh FC, Yang RC, Boyle T (1999) Microsolft Window Besed Freeware for Population Genetc Anazysis. POPOGEN, versão 1.31. 